\title{
DETERMINATION OF NITRATE AND NITRITE CONTENT IN ZONAR MILK SERUM AND DERIVED DAIRY DRINKS USING ION-PAIR REVERSED-PHASE HIGH PERFORMANCE LIQUID CHROMATOGRAPHY*
}

\author{
MIUȚA FILIP ${ }^{a}{ }^{*}$, DOINA PRODAN ${ }^{a}$, MARIOARA MOLDOVAN ${ }^{a}$, \\ MIHAELA VLASSA ${ }^{a}$
}

\begin{abstract}
The presence of nitrite and nitrate in milk and dairy products may cause serious health problem for consumers. Thus, a simple and accurate ion-pair reversed-phase high performance liquid chromatographic (IP-RP-HPLC) method has been developed and validated for determination of nitrite and nitrate in some dairy drinks based on Zonar Milk Serum.

The separation was achieved on a Synergy Hydro-RP polar endcapped $\mathrm{C} 18,80 \AA, 4 \mu \mathrm{m}(250 \times 4.6 \mathrm{~mm})$ column using isocratic elution with $0.01 \mathrm{M}$ $n$-octylamine and methanol, $90: 10(\mathrm{v} / \mathrm{v})$ at $\mathrm{pH}=7$; with flow rate of $1 \mathrm{~mL} \cdot \mathrm{min}^{-1}$ and detection at $214 \mathrm{~nm}$ and $25^{\circ} \mathrm{C}$. A linear response $\left(R^{2} \geq 0.9994\right)$ was observed in the range between 3.125 and $75 \mu \mathrm{g} \mathrm{mL}^{-1}$ for the nitrite and nitrate standard solutions. The limits of detection (LOD) and quantification (LOQ) were found as $0.25 \mu \mathrm{g} \mathrm{mL}^{-1}$ and $0.8 \mu \mathrm{g} \mathrm{mL}^{-1}$ for nitrite and $0.4 \mu \mathrm{g} \mathrm{mL}^{-1}$ and $1.2 \mu \mathrm{g} \mathrm{mL} \mathrm{m}^{-1}$ for nitrate, respectively.

The method was validated according to $\mathrm{ICH}$ guidelines with respect to selectivity, linearity, detection and quantitation limits, accuracy, precision. The good analytical performance verified for this method indicates that it is suitable the monitoring of nitrite and nitrate in dairy drinks based on Zonar Milk Serum.
\end{abstract}

Keywords: Nitrite, Nitrate, IP-RP-HPLC, validation, Zonar Milk Serum dairy drinks

\footnotetext{
a *This paper was presented at the „1st SChR Symposium of Separation Science Section "Separation Sciences in the RChS Centenary" Organized by the Separation Science Section of SChR, October 26th, 2018, Cluj-Napoca, Romania"

"Babeș-Bolyai” University, „Raluca Ripan” Institute for Researh in Chemistry, 30 Fântânele Street, 400294 Cluj-Napoca, Romania.

*Corresponding author: filip_miuta@yahoo.com; filip.miuta@ubbcluj.ro
} 


\section{INTRODUCTION}

Nitrite and nitrate are naturally compounds occurring in foods, especially plant foods and vegetables, and are also used as additives in industrially processed foods. Major sources of exogenous nitrate exposure are vegetables and drinking water, whereas processed meat and animal food products are major nitrite-containing foods [1].

Nitrites and nitrates are considered harmful food additives. Maximum levels of nitrates (E 251 - E 252) have been defined in Annex II to Regulation (EC) No 1333/2008 on food additives and they were previously evaluated by the EU Scientific Committee for Food, the Joint FAO/WHO Expert Committee on Food Additives, and the European Food Safety Authority. The current acceptable daily intakes for sodium and potassium nitrate (expressed as nitrite ion) are both at $0-3.7 \mathrm{mg} \cdot \mathrm{kg}^{-1}$ body weight per day [2].

The increasing of nitrite and nitrate level in food products as cheese, meat, and fish, commonly used as curing and preservatives, has cause serious hazards to animal and human. The presence of nitrates and nitrites in food is associated with an increased risk of gastrointestinal cancer and methemoglobinemia at infants [3].

The widespread use of fertilizers, domestic, agricultural, and industrial wastes have increased the chances of nitrite and nitrate into manufactured dairy products [4].

Traditionally, milk whey has been viewed as a by-product of dairy industry with little value for the consumers. However, in last decades, there is a growing interest focused on the nutritional properties of whey proteins and whey-derived products and its role upon human health. Therefore, the detection of nitrate and nitrite in milk is of great importance to the consumer's health [5].

The nitrate may naturally be present in milk and the level of it depends on the quality of feeding materials (i.e. water, feeds) of cows. Part of the nitrates from the ration of ruminants are converted into assimilable products in the rumen, and some will be found in the blood, organs and muscles that will be eliminated in the urine and even milk.

A study for determination of nitrate and nitrite in 100 samples of milk and milk powder in Taiwan, show that the average nitrate concentration of colostrum fortified milk, it ranged from 14.1 to $136 \mathrm{ppm}$, while in ordinary milk ranged between 57.9 and $157.6 \mathrm{ppm}$. For the whey fortified milk the average nitrate concentration ranged from 42.6 to $242.8 \mathrm{ppm}$ [11].

Another study shows that the level of nitrate and nitrite content in both raw milk samples or samples collected during cold and warm months were $52.87 \pm 26.9$ and $70.48 \pm 29.8 \mathrm{mg} \cdot \mathrm{L}-1$ respectively. These may be attributed to both external sources such as contamination by nitrate fertilizers, forage and agricultural drinking water [14]. 
Osvat at al., determined the nitrate content in mixed milk, pasteurized milk, sheep's milk and reconstituted milk powder from Romanian areas, of lasi, Cluj-Napoca and Timisoara. They found that at the four categories of milk investigated, the maximum nitrate level for all categories was below $10 \mathrm{mg} \cdot \mathrm{L}^{-1}$ [15].

Several analytical methods for the determination of nitrite and nitrate in different matrices have been reported [19]. These methods include ion chromatography (IC) [4, 10, 11], high performance liquid chromatography (HPLC) [6-8, 12, 13], differential pulse voltammetry [8], capillary electrophoresis [9] or others analytical method [19].

During the past decade, IC and HPLC methods have been developed for analysis of nitrite and nitrate, due to by their accurate and precise determinations of the compounds $[4,10,12,13]$.

Because milk is one of the most important sources for infant and babies and adults it is necessary to control the level of nitrite and nitrate in milk and dairy products, for their excess not to cause it serious health problems for consumers [4].

In this study, a simple and rapid IP-RP-HPLC method with UV detection was optimized and validated for quantification of nitrite and nitrate in five samples of dairy drinks based on Zonar Milk Serum.

\section{RESULTS AND DISCUSSION}

\section{Developing and validation of method}

The use of HPLC for the quantification and separation of the nitrite and nitrate in different matrices is one of the most commonly used techniques in the laboratory.

Thus, the ion-pair chromatographic method developed by the Najdenkoska [12] was improved, optimized and validated by us, in order to identify and quantify the nitrite and nitrate in dairy drinks based on Zonar Milk Serum. By using a Synergy Hydro-RP polar endcapped C18 column shows increased hydrophobic retention and polar retention compared to other $\mathrm{C} 18$ phases.

Also, in this method is takes place a mobile phase modification that allows the reversed-phase column (typically C-18) to separate ionic analytes which would typically not be retained otherwise.

Nitrates and nitrites are ionized compounds. Modification of the mobile phase occurs through the addition of the ion-pair reagent, $n$-octylamine, as a component [6]. As using ion-pair reagent which increase retention time and improve separation of analytes, the isocratic elution mode was adopted. 
The validation of this analytical method was evaluated by the parameters: selectivity, linearity, limit of detection (LOD), limit of quantification (LOQ), accuracy and precision [16].

Selectivity was tested by comparing the chromatogram of a standard solution of sodium nitrite and sodium nitrate, with those of Zonar Milk Serum dairy drinks (Figure 1).

Our result showed that there is no interference at the retention time of nitrite and nitrate in blank and spiked Zonar Milk Serum samples. The retention time of nitrite and nitrate presented chromatograms were at 8.16 and 9.2 min, respectively.

Linearity was assessed based on a plot of the analyte peak area against analyte concentration.

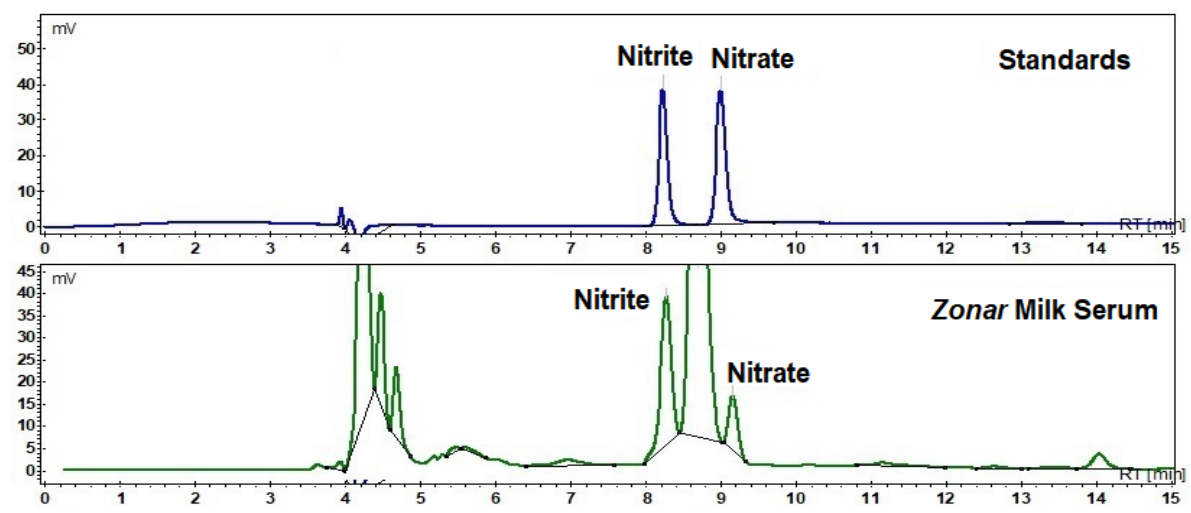

Figure 1. HPLC chromatograms of the standard mixture and Zonar Milk Serum sample.

The results proved to be linear and acceptable, as the correlation coefficients $\left(R^{2}\right)$ were greater than 0.9994 for the two analytes (Table 1). Calibration range was between $3.125-75 \mu \mathrm{g} \cdot \mathrm{mL}^{-1}$ which is significant for our determinations.

Table 1. Linear regression data, $L O D$ and $L O Q$ of the dairy beverages.

\begin{tabular}{|l|l|l|}
\hline Parameters / compound & Nitrite $\left(\mathrm{NO}_{2}{ }^{-}\right)$ & Nitrate $\left(\mathrm{NO}_{3}{ }^{-}\right)$ \\
\hline${ }^{a} \mathrm{RT}[\mathrm{min}]$ & 8.16 & 9.02 \\
\hline${ }^{\mathrm{b}}$ Calibration curve & $\mathrm{Y}=1.6294 \mathrm{X}+0.73367$ & $\mathrm{Y}=1.71245 \mathrm{X}+0.68354$ \\
\hline${ }^{\mathrm{c}}$ Regression coefficient $R^{2}$ & 0.9994 & 0.9997 \\
\hline Linear range $\left(\mu \mathrm{g} \mathrm{mL}{ }^{-1}\right)$ & $3.125-75$ & $3.125-75$ \\
\hline${ }^{\mathrm{d}} \mathrm{LOD}(\mu \mathrm{g} \mathrm{mL}-1)$ & 0.25 & 0.4 \\
\hline${ }^{\mathrm{d}} \mathrm{LOQ}(\mu \mathrm{g} \mathrm{mL}-1)$ & 0.8 & 1.2 \\
\hline
\end{tabular}

${ }^{a} \mathrm{RT}$, the retention time; ${ }^{\mathrm{b}} \mathrm{Y}$, the peak area; $\mathrm{X}$, the concentration of reference compound $\left(\mu \mathrm{g} \cdot \mathrm{mL}^{-1}\right) ;{ }^{\mathrm{c}} R^{2}$ regression coefficient of calibration curve $\left(\mathrm{n}=6\right.$, six points); ${ }^{\mathrm{d}} \mathrm{LOD}$, the limit of detection $(S / N=3) ;{ }^{d} L O Q$, the limit of quantification $(S / N=10)$; 
The LOD values was $0.25 \mu \mathrm{g} \mathrm{mL}^{-1}$ for nitrite and $0.4 \mu \mathrm{g} \mathrm{mL}^{-1}$ for nitrate, respectively, and the $L O Q$ values was $0.8 \mu \mathrm{g} \mathrm{mL}^{-1}$ for nitrite and $1.2 \mu \mathrm{g} \mathrm{mL}-1$ for nitrate, respectively. This low values indicate a good sensitivity of the proposed method. In all samples the concentrations of both nitrate and nitrite were higher than the method LOD levels.

The intra-day and inter-day precision were expressed as percentage of relative standard deviation (\% RSD).

The precision data are shown in Table 2 and the results show the \% RSD is lower than $4.85 \%$ for nitrite and $5.13 \%$ for nitrate, respectively. In addition, there were no significant differences between the results of the test, indicating that the precision of the proposed method was satisfactory.

Table 2. Intra- and inter-day precision of nitrite and nitrate

\begin{tabular}{|c|c|c|c|c|c|}
\hline \multirow[b]{2}{*}{ Comp. } & \multirow[b]{2}{*}{$\begin{array}{l}\text { Conc. } \\
\left(\mu \mathrm{g} \cdot \mathrm{mL}^{-1}\right)\end{array}$} & \multicolumn{2}{|c|}{ Intra-Day Precision $(\mathrm{n}=6)$} & \multicolumn{2}{|c|}{ Inter-Day Precision $(\mathrm{n}=9)$} \\
\hline & & $\begin{array}{c}\text { Measured conc. } \\
\text { Mean }^{\mathrm{a}} \pm \mathrm{SD}^{\mathrm{b}},\left(\mu \mathrm{g} \cdot \mathrm{mL}^{-1}\right.\end{array}$ & $\begin{array}{c}\mathrm{RSD}^{\mathrm{c}} \\
(\%)\end{array}$ & $\begin{array}{c}\text { Measured conc. } \\
\text { Mean }{ }^{\mathrm{a}} \pm \mathrm{SD} \mathrm{b}^{\mathrm{b}},\left(\mu \mathrm{g} \cdot \mathrm{mL}^{-1}\right.\end{array}$ & $\begin{array}{c}\mathrm{RSD}^{\mathrm{c}} \\
(\%)\end{array}$ \\
\hline \multirow{3}{*}{$\begin{array}{l}\text { Nitrite } \\
\left(\mathrm{NO}_{2}{ }^{-}\right)\end{array}$} & 50 & & & $50.34 \pm 2.44$ & 4.85 \\
\hline & 12.5 & $12.35 \pm 0.41$ & 3.36 & $12.35 \pm 0.35$ & 2.86 \\
\hline & 3.123 & & & $3.023 \pm 0.045$ & 1.50 \\
\hline \multirow{3}{*}{$\begin{array}{l}\text { Nitrate } \\
\left(\mathrm{NO}_{3}^{-}\right)\end{array}$} & 50 & & & $50.34 \pm 2.58$ & 5.13 \\
\hline & 12.5 & $12.27 \pm 0.59$ & 4.81 & $11.98 \pm 3.39$ & 3.30 \\
\hline & 3.125 & & & $3.128 \pm 0.05$ & 1.62 \\
\hline
\end{tabular}

${ }^{\mathrm{a}}$ Mean $=$ Average of $n$ determination; ${ }^{\mathrm{b}} \mathrm{SD}=$ Standard deviation; ${ }^{\mathrm{c}} \mathrm{RSD}=$ Relative standard deviation; comp. $=$ compound; conc . concentration .

In Table 3 are presented the recovery degree values of nitrite and nitrate in studied sample at three different concentration levels of $3.125 \mu \mathrm{g} \cdot \mathrm{mL}^{-1}$ (low level), $12.5 \mu \mathrm{g} \cdot \mathrm{mL}^{-1}$ (intermediate level) and $50 \mu \mathrm{g} \cdot \mathrm{mL}^{-1}$ (high level), of standard mixtures added to the Zonar Milk Serum sample. The recoveries are calculated as an average of the triplicate analyses.

Table 3. Recovery degree values of nitrite and nitrate in samples

\begin{tabular}{|l|l|l|l|l|l|l|}
\hline Compound & \multicolumn{2}{|c|}{$\begin{array}{c}\text { Recovery at low level } \\
(\%)\end{array}$} & $\begin{array}{c}\text { Recovery at intermediate } \\
\text { level }(\%)\end{array}$ & \multicolumn{2}{c|}{$\begin{array}{c}\text { Recovery at high level } \\
(\%)\end{array}$} \\
\cline { 2 - 7 } & Mean ${ }^{\mathrm{a}} \pm \mathrm{SD}^{\mathrm{b}}$ & $\mathrm{RSD}^{\mathrm{c}}$ & Mean & ${ }^{\mathrm{a}} \pm \mathrm{SD}^{\mathrm{b}}$ & $\mathrm{RSD}^{\mathrm{c}}$ & Mean \\
& $\pm \mathrm{SD}^{\mathrm{b}}$ & $\mathrm{RSD}^{\mathrm{c}}$ \\
\hline Nitrite $\left(\mathrm{NO}_{2}{ }^{-}\right)$ & $98.67 \pm 1.27$ & 1.29 & $100.98 \pm 2.73$ & 2.70 & $104 \pm 4.45$ & 4.37 \\
\hline Nitrate $\left(\mathrm{NO}_{3}{ }^{-}\right)$ & $97.88 \pm 1.85$ & 1.89 & $101.40 \pm 3.29$ & 3.25 & $100.68 \pm 5.12$ & 5.09 \\
\hline
\end{tabular}

${ }^{a}$ Mean $=$ Average of $n$ determination; ${ }^{b} \mathrm{SD}=$ Standard deviation; ${ }^{\mathrm{C}} \mathrm{RSD}=$ Relative standard deviation. 
Mean recovery values for nitrite and nitrate concentration in the spiked samples at different levels were found to be between $98.88-104 \%$ for nitrite and $97.88-101.4 \%$ for nitrate. The RSD\% values for recovery varied between $1.29-4.37 \%$ for nitrite and $1.89-5.09 \%$ for nitrate, respectively (Table 3). These parameters were evaluated as acceptable for validated HPLC method.

\section{Application of IP-RP-HPLC method for quantification of nitrites and nitrates in dairy drinks based on Zonar Milk Serum}

The analytical method were applied for analysis of in five samples of dairy drinks based on Zonar Milk Serum.

The results obtained are shown in Figure 2. The samples noted with 1 and -2 represented Zonar dairy drinks obtained from different milk batches.

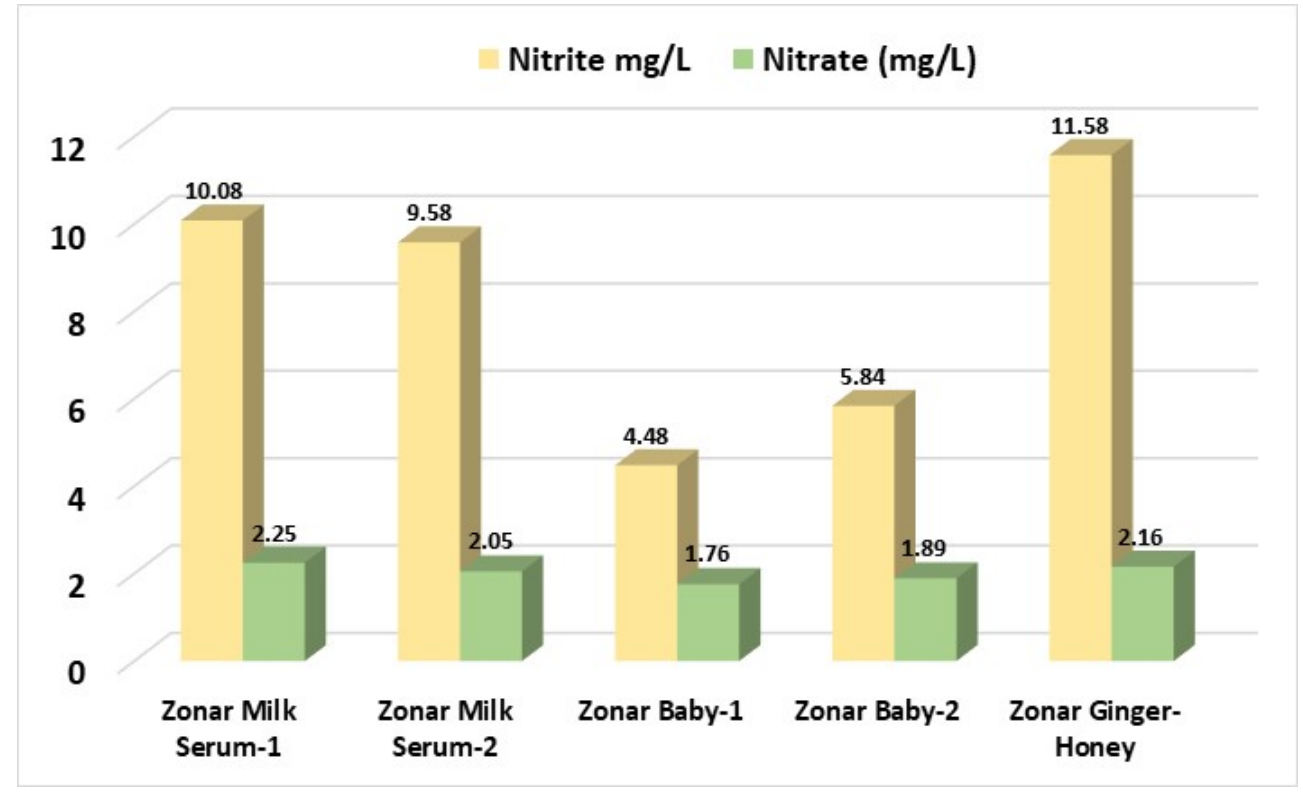

Figure 2. Nitrite and nitrate content in dairy drinks based on Zonar Milk Serum.

Thus, it can be observe that the amounts of nitrite and nitrate in dairy drinks based on Zonar Milk Serum were found in ranges of 4.48 $11.58 \mathrm{mg} \cdot \mathrm{L}^{-1}$ and $1.76-2.25 \mathrm{mg} \cdot \mathrm{L}^{-1}$, respectively. 
In Zonar Baby-1 and -2 samples, the dairy drinks for babies, we found the smallest amounts of nitrite $\left(4.48\right.$ and $\left.5.84 \mathrm{mg} \cdot \mathrm{L}^{-1}\right)$ and nitrate (1.76 and $1.89 \mathrm{mg} \cdot \mathrm{L}^{-1}$ ) and much smaller then milk samples [11, 15]. All samples studied contain nitrites and nitrates below the permissible limit of $200 \mathrm{mg} \cdot \mathrm{L}^{-1}$ by EU regulation in baby food (milk) [2].

These results obtained are comparable with literature data. The average nitrate concentrations of whey fortified milk ranged from 42.6 to $242.8 \mathrm{ppm}$ and for ordinary milk ranged from 57.9 to $157.6 \mathrm{ppm}$ in Taiwan [11]. The quantity of nitrate in whey samples determined by sequential injection using an in-line cadmium-reducing column were find between 0.91 and $4.76 \mathrm{mg} \cdot \mathrm{L}^{-1}$ [18]. In others dairy products, mean nitrite and nitrate content ranged $0.14-0.45 \mathrm{mg} 100 \mathrm{~g} \mathrm{~g}^{-1}$ and $1.26-5.75 \mathrm{mg} 100 \mathrm{~g}^{-1}$ [1]. An investigation on levels of nitrate in 95 fresh milk samples, in Romania, carried out during the years $2007-2010$, show that the mean level of nitrate was 2.66, $2.39,3.08$, and $2.67 \mathrm{mg} \cdot \mathrm{L}^{-1}$ respectively. The level of nitrate in 40 pasteurized milk samples was 2.48 and $2.75 \mathrm{mg} \cdot \mathrm{L}^{-1}$ in 2009 and 2010 , respectively [15].

\section{CONCLUSIONS}

A simple and efficient IP-RP-HPLC method was successfully optimized and validated for quantification of nitrite and nitrate in some dairy drinks based on Zonar Milk Serum.

The developed RP-HPLC method was selective providing satisfactory accuracy with low limits of detection. It has ensured a precise quantification of nitrite and nitrate in five samples of dairy drinks based on Zonar Milk Serum. In Zonar Baby samples were obtained the smallest amounts of nitrite and nitrate.

The results of our study indicate that nitrate and nitrate levels in all samples were less then maximum limits accepted by EU regulation in baby food (milk).

Therefore, investigation of nitrite and nitrate contents in different foods would be of great importance for both safety and nutrition intake recommendation.

\section{EXPERIMENTAL SECTION}

\section{Chemicals and reagents}

All reagents were of analytical grade. Sodium nitrite and sodium nitrate and $n$-octylamine were purchased from Sigma-Aldrich (USA, Germany). 
Analytical grade water was obtained from Milli-Q Ultrapure water purification system (Millipore, USA). The methanol of HPLC grade and phosphoric acid were purchased from Merck (Darmstadt, Germany).

\section{Instrumentation and chromatographic conditions}

The analyses were performed using an High Performance Liquid Chromatograph Jasco 980 (Japan) equipped with Intelligent HPLC pump (Model PU-980), low pressure gradient unit (Model LG-980-02), in-line degasser (Model DG-980-50), intelligent Column Thermostat (CO-2060), UV-Vis detector (Model UV-970/975), manual injection through a Rheodyne valve of $20 \mu \mathrm{L}$ loop (Hamilton Rheodyne Syringe, $50 \mu \mathrm{L}$ ). Data collection and analyses were performed using ChromPass software. The separation was achieved on a Synergy Hydro-RP polar endcapped C18, 80 $4 \mu \mathrm{m}(250 \times$ $4.6 \mathrm{~mm}$ ) column using isocratic elution. The mobile phase was composed of the mixture of $0.01 \mathrm{M} n$-octylamine and methanol in a 90:10 $(\mathrm{v} / \mathrm{v})$ ratio, at $\mathrm{pH}=7$ with phosphoric acid. All solutions were degassed and filtered through a $0.45 \mu \mathrm{m}$ pore filter membrane (Nordic Chemicals, Romania). Using these chromatographic conditions, the retention times of nitrite and nitrate could be confirmed by the standards injection.

\section{HPLC sample preparation}

A volume of $2 \mathrm{~mL}$ of studied sample was diluted with $4 \mathrm{~mL}$ Millipore water and filtered through a $0.45 \mu \mathrm{m}$ syringe filter and injected in the HPLC system.

For this study we use five dairy drinks based on Zonar Milk Serum: Zonar Milk Serum - $\mathrm{n}$, is dairy drinks based on Zonar Milk Serum obtained from different milk batches, $\mathrm{n}=2$; Zonar Baby - $\mathrm{n}$ is a dairy drinks based on Zonar Milk Serum for baby children, from different batches, $\mathrm{n}=2$; Zonar Ginger-Honey is a dairy drinks based on Zonar Milk Serum with ginger extract and honey.

\section{Preparation of the standard solution}

Standard stock solutions $\left(1 \mathrm{mg} \cdot \mathrm{mL}^{-1}\right)$ for each standard were prepared by dissolving the solid compound in Millipore water. The solutions were kept in the refrigerator at $4^{\circ} \mathrm{C}$ and were stable for three weeks. Working standard solutions were prepared as needed by appropriate dilution of the concentrated stock solutions in water.

\section{Method validation}

In the validation of the analytical method used to quantify the nitrite and nitrate in dairy drinks based on Zonar Milk Serum, the following parameters were determined: selectivity, linearity, limit of detection (LOD), limit of quantification (LOQ), accuracy and precision [16]. 
Selectivity was tested by comparing the chromatogram of a standard solution of sodium nitrite and sodium nitrate compounds, with those of studied samples.

Linearity was assessed based on a plot of the analyte peak area against analyte concentration. Calibration range was between $3.125-75$ $\mu \mathrm{g} \cdot \mathrm{mL}^{-1}$ from each standard.

$L O D$ and $L O Q$ parameters were calculated as the concentration corresponding to three and ten times respectively, of the background noise of the blank (signal-to-noise ratio, $\mathrm{S} / \mathrm{N}$ ).

The intra-day precision was obtained from the data of the 6 replicate analysis of $12.5 \mu \mathrm{g} \cdot \mathrm{mL}^{-1}$ standard concentration; Inter-day precision (three replicate for three consecutive days) determinations were performed on the three different concentrations of standard solutions; The precision was expressed as percentage of relative standard deviation (\% RSD).

Accuracy of the method was study the recovery degree. Three different concentration levels of $3.125 \mu \mathrm{g} \cdot \mathrm{mL}^{-1}$ (low level), $12.5 \mu \mathrm{g} \cdot \mathrm{mL}^{-1}$ (intermediate level) and $50 \mu \mathrm{g} \cdot \mathrm{mL}^{-1}$ (high level) of standard mixtures were added to the Zonar Milk Serum sample. Spiked samples were prepared in triplicate. The recovery was calculated as follows equation:

$$
\text { Recovery } \%=\frac{\text { Detected amount }- \text { Original amount }}{\text { Spiked amount }} \cdot 100
$$

\section{ACKNOWLEDGMENTS}

This work was financially supported by the Romanian Programme for Research, Development and Innovation PNCDI III, Cod: PN-III-P2-2.1-BG2016-0335, Contract no 28BG/2016, http://www.usamvcluj.ro/profi-zonar/.

The authors thank to S.C. EmbryOm Capital investment S.R.L., SatuMare, Romania for providing the dairy drinks samples.

\section{REFERENCES}

1. Z. Bahadoran, P. Mirmiran, S. Jeddi, F. Azizi, A. Ghasemi, F. Hadaegh, Journal of Food Composition and Analysis, 2016, 51, 93.

2. European Commission. (2011). Commission Regulation (EC) No. 1333/2008 of the European Parliament and of the Council by establishing a Union list of food additives, Re-evaluation of sodium nitrate (E 251) and potassium nitrate (E 252) as food additives, EFSA Journal 2017, 15(6), 4787. 
3. C.S. Bruning-Fann, J.B. Kaneene, Veterinary and human toxicology, 1993, 35, 521.

4. S. Chamandust, M.R. Mehrasebi, K. Kamali, R. Solgi, J. Taran, F. Nazari, MJ. Hosseini, International Journal of Food Properties, 2016, 19, 1983.

5. Ty B. Wagoner, E.A. Foegeding, Food Hydrocolloids, 2017, 63, 130-138.

6. I.M.P.L.V.O. Ferreira, S. Silva, Talanta, 2008, 74, 1598.

7. T. Tamme, M. Reinik, M. Roasto, K. Juhkam, T. Tenno, A. Kiis, Food Additives and Contaminants, 2006, 23 (04), 355.

8. M. Ćurčić Jovanović, M. Djukić, I. Vasiljević, M. Ninković, M Jovanović, Journal of Serbian Chemical Society, 2007, 72 (4), 347.

9. D.F. Betta, L. Vitali, R. Fett, A.C. Costa, Talanta, 2014, 22, 23.

10. I. Shah, A. Petroczi, R.A. James, D.P. Naughton, Analytical \& Bioanalytical Techniques, 2013, S12, 003. doi:10.4172/2155-9872.S12-003.

11. T.S. Yeh, S.F. Liao, C.Y. Kuo, W.I. Hwang, Journal of Food and Drug Analysis, 2013, 21 (1), 73.

12. A. Najdenkoska, Journal of Agricultural, Food and Environmental Sciences, 2016, 67,33 .

13. S.S. Chou, J.C. Chung, D.F. Hwang, Journal of Food and Drug Analysis, 2003, 11(3), 233.

14. T.H. Mohamed, Assiut Journal of Agricultural Sciences, 2010, 42 (2), 106.

15. M. Osvat, V. Bara, Analele Universității din Oradea Fascicula Ecotoxicologie, Zootehnie si Tehnologii de Industrie Alimentară, 2010, 9(9), 1.

16. $\mathrm{ICH}$ harmonised tripartite guideline. Validation of analytical procedures: Text and methodology Q2 (R1). 2005. http://www.ich.org/fileadmin/Public_Web_Site/ ICH_Products/Guidelines/Quality/Q2_R1/Step4/Q2_R1_Guideline.pdf, pp. 1-17.

17. M.N. Moshoeshoe, V. Obuseng, S. Afr. J. Chem., 2018, $71,79$.

18. M.J. Reis Lima, S.M.V. Fernandes, A.O.S.S. Rangel, International Dairy Journal 2006, 16, 1442.

19. Q-H. Wang, L-J. Yu, Y. Liu, L. Lin, R. Lu, J. Zhu, L. He, Z-L. Lu, Talanta, 2017, $165,709$. 